Jurusan Sejarah, Sosiologi dan Perpustakaan (Volume 2, Nomor 1, Tahun 2020)

\title{
PENYALAHGUNAAN OBAT BATUK KOMIX SEBAGAI FENOMENA PERILAKU PENYIMPANGAN SOSIAL DI KALANGAN REMAJA DESA SAPEKEN, SAPEKEN, SUMENEP DAN POTENSINYA SEBAGAI SUMBER BELAJAR SOSIOLOGI DI SMA
}

\author{
Agus Salim, Tuty Maryati, I Gusti Made Arya Suta Wirawan \\ Jurusan Sejarah, Sosiologi, dan Perpustakaan \\ Universitas Pendidikan Ganesha \\ Singaraja, Indonesia
}

e-mail: \{agus.salim, tuty.maryati, arya.suta\}@undiksha.ac.id

\begin{abstract}
Abstrak
Fenomena penyalahgunaan Obat Batuk Komix yang dilakukan remaja Desa Sapeken semakin meluas. Meluasnya peilaku penyalahgunaan Obat yang dianggap hanya dilakukan oleh remaja perkotaan, kini telah menyebar. Hal ini menunjukkan adanya pengaruh buruk yang terjadi secara meluas. Penelitian ini bertuan untuk 1) Menjelaskan alasan remaja Desa Sapeken, Sapeken, Sumenep melakukan penyalahgunaan Obat Batuk Komix. 2) Menganalisis upaya yang dilakukan oleh tokoh masyarakat, keluarga, kelompok masyarakat dan pemerintah dalam menanggulangi penyalahgunaan Obat Batuk Komix yang terjadi di Desa Sapeken. 3) Menjelaskan aspek-aspek yang terdapat dari peri penyalahgunaan Obat Batuk Komix sebagai fenomena perilaku penyimpangan sosial di kalangan remaja Desa Sapeken, Sapeken, Sumenep yang bisa dimanfaatkan sebagai sumber belajar Soiologi di SMA. Penelitian ini menggunakan metode kualitatif dengan tahap-tahap; 1) Teknik penetuan lokasi penelitian. 2) Jenis dan sumber data, melalui data primer dengan teknik purposive sampling, Data Skunder. 3) Teknik pengumpulan data, melalui teknik observasi, wawancara dan studi dokumen. 4) Teknik keabsahan data dengan cara analisis data dengan cara reduksi data, penyajian data, penarikan kesimpulan.
\end{abstract}

Kata kunci: Fenomena, Penyalahgunaan Obat Batuk Komix, Perilaku Penyimpangan Sosial, Sumber Belajar.

\begin{abstract}
The phenomenon of abuse of Komix Cough Medicine by teenagers in Sapeken Village is increasingly widespread. Widespread drug abuse behavior that is considered only carried out by urban youth, has now spread. This shows the existence of bad influences that occur widely. This study aims to 1) Explain the reasons why teenagers of Sapeken Village, Sapeken, Sumenep commit abuse of Komix Cough Medicine. 2) Analyzing the efforts made by community leaders, families, community groups and the government in tackling the abuse of Komix Cough Medicine that occurred in Sapeken Village. 3) Explain aspects of the Komix cough drug abuse as a phenomenon of social deviant behavior among adolescents in the villages of Sapeken, Sapeken, Sumenep which can be used as a source of learning for Soiology in high school. This study uses a qualitative method with stages; 1) Determination of research location techniques. 2) Types and sources of data, through primary data with a purposive sampling technique, Secondary Data. 3) Data collection techniques, through observation techniques, interviews and document studies. 4) Data validity techniques by means of data analysis by data reduction, data presentation, drawing conclusions.
\end{abstract}

Keywords : Phenomenon, Komix Cough Abuse, Social Abuse Behavior, Learning Resources. 


\section{PENDAHULUAN}

Obat merupakan bahan yang digunakan oleh semua makhluk hidup untuk bagian luar dan dalam tubuh guna mencegah, meringankan, dan menyembuhkan penyakit. Sedangkan menurut undang-undang obat merupakan bahan campuran untuk dipergunakan dalam menentukan diagnosis, mencegah, mengurangi, menghilangkan, menyembuhkan penyakit, gejala penyakit, luka, kelainan jasmani, rohani pada manusia, hewan dan untuk memperelok tubuh manusia. Obat zat kimia dapat mengubah pikiran, suasana hati dan prilaku seseorang. Dalam kebijakan obat nasional, obat merupakan sediaan atau paduan bahan-bahan yang siap digunakan untuk mempengaruhi sistem fisiologi atau keadan patologi dalam rangka penetapan diagnosa, pencegahan, penyembuhan, pemulihan, dan untuk meningkatkan kesehatan. (Anshari, M. 2009).

$$
\text { Meskipun obat dapat }
$$

menyembuhkan, tetapi obat dapat menjadi racun tergantung pada cara penggunaannya. Oleh karena itu dalam menggunakan obat perlu diketahui efek obat tersebut, penyakit apa yang diderita, berapa dosisnya serta kapan dan dimana obat itu digunakan. Batas jarak sebagai obat dan racun adalah pendek hal ini tergantung cara dan dosis (Refeiater, 2011).

Sedangkan kenyataannya sering terjadi penyalahgunaan obat yang seharusnya bersifat menyembuhkan berubah menjadi racun. Salah satu contoh obat yang disalahgunakan adalah Obat Batuk Komix. Fenomena ini pernah terjadi di Ambon pada selasa 13 februari 2018. Bukan hanya di Ambon, pada tahun 2014 kasus yang serupa juga terjadi di Desa Sapeken, Sapeken, Sumenep. Dimana penyalahgunaan Obat batuk Komix ini dilakukan oleh kalangan remaja Desa Sapeken sebagai media untuk mabukmabukan.

Penyalahgunaan Obat Batuk Komix yang terjadi di Desa Sapeken, Sapeken, Sumenep terjadi pada tahun 2014-2018 dan sampai sekarang masih ada. Pada tahun 2017, dua pelaku penyalahgunaan Obat Batuk Komix tersebut meninggal dunia dan beberapa pelaku muntahmuntah dan pingsan sehingga mereka terpaksa dilarikan ke Puskesmas terdekat. Penyalahgunaan Obat Batuk Komix tersebut dilakukan oleh remaja berusia 1320 tahun, di antara mereka ada yang masih berstatus pelajar SMP, SMA dan ada juga yang tidak bersekolah. Penulis juga menemukan fakta di lapangan bahwa para pelaku tidak hanya dari kalangan laki-laki, namun di antara mereka ada dari perempuan meskipun mayoritas pelaku adalah laki-laki

Penyalahgunaan Obat Batuk Komix ini dilakukan secara sengaja untuk mendapatkan efek mabuk, Ngefly dan mengikuti gaya teman. Sehingga mengakibatkan perilaku menyimpanglainnya yang mengganggu masyarakat. Diantaranya, mabukmabukan, tawuran antar individu dan/atau kelompok, ugal-ugalan saat mengendarai sepeda motor, bolos sekolah, menonton fidio porno, serta menjual barang berharga orang tuanya dengan harga murah.

Tujuan dari penelitian ini yaitu di antaranya; Menjelaskan alasan remaja Desa Sapeken melakukan penyalahgunaan Obat Batuk Komix, Menganalisis upaya apa saja yang dilakukan oleh tokoh masyarakat, keluarga, komunitas dan pemerintah dalam menanggulangi penyalahgunaan Obat Batuk Komix yang terjadi di Desa Sapeken.

Selain itu, hasil penelitian ini juga bisa menunjang guru dalam memaparkan mata pelajaran Sosiologi di Sekolah Menengah Atas (SMA), khususnya pada kelas XI yang berkaitan dengan materi pembelajaran permasalahan sosial dalam masyarakat. Hal ini bisa dilihat dari silabus mata pelajaran Sekolah Menengah Atas/Madrasah Aliyah (SMA/MA), Kurikulum 2013 (K-13), pada Kompetensi Dasar (KD) 3.2 dan Kompetensi Dasar (KD) 4.2 . 


\section{Tipe Artikel}

Hasil Kajian Penelitian yang relevan dengan penelitian yang penulis lakukan terkait dengan penyimpangan sosial penyalahgunaan Obat Batuk Komix di Desa Sapeken, sapeken, sumenep ini memiliki relevansi dengan beberapa penelitian diantaranya yang sudah dilakukan Yakni;

Penelitian Yonir Wenny Maylinda, (2016), dalam skripsi yang berjudul "Motif Pemabuk Studi Kasus Kebiasaan Menggunakan Media Obat Batuk Komix di kalangan Remaja Kelurahan Purwanegara". Dalam penelitian ini Maylinda bertujuan mengetahui faktor pendorong, adapun subjek penelitian yang dilakukan oleh maylinda adalah tiga orang yang dianggap pemakai ( pemebuk menggunakan Obat Batuk Komix di kalangan kelurahan Purwanegara. Metode yang digunakan dalam penelitian ini yaitu menggunakan metode kualitatif kualitatif dengan menggunakan pendekatan studi kasus yang dilakukan melalui riwayat hidup, wawancara mendalam yang digunakan sebagai dasar untuk mengetaahui latar belakang pelaku. Wawancara dilakuakan dengan cara berpatokan pada landasan teori yang digunakan, observasi dilakukan saat wawancara berlangsung.

Dari hasil penelitian yang dilakukan oleh Maylinda mengungkapkan bahwa para remaja melakukan mabuk menggunakan Obat batuk Komix dipengaruhi oleh kurangnya kegiatan positif, kelompok bermain yang kurang baik atau lingkungan tempat pelaku tinggal., kurangnya perang orang tua dalam memberikan pengawasan kepada anaknya, dan mudahnya mendapatkan Obat Batuk Komix dengan harga murah.

Skripsi Dewi Palupi Harjatiningsih, (2015) "Analisis faktor-faktor yang mempengaruhi prilaku menyimpang pada siswa-siswi SMA Negeri 1 Parung" Penelitian ini bertujuan untuk mengetahui apa saja faktor-faktor yang mempengaruhi perilaku menyimpang dan seberapa besar faktor-faktor tersebut menyebabkan siswa/i berperilaku menyimpang. Penelitian ini menggunakan pendekatan kuantitatif populasi dalam penelitian ini adalah siswa-siswi SMA Negeri 1 Parung angkatan 2013-2014 sampel dalam penelitian ini adalah 280 siswa/i. Teknik pengumpulan data yang digunakan dalam penelitian ini adalah dengan menggunakan angket.

Temuan dari hasil penelitian ini menunjukkan bahwa secara deskriptif faktor-faktor yang mempengaruhi perilaku menyimpang meliputi: faktor pertemanan $(36,4 \%)$, faktor hubungan antar tetangga $(2,7 \%)$, faktor keluarga $(12,1 \%)$, dan faktor media massa $(11,2 \%)$, dan untuk siswa/i yang melakukan perilaku menyimpang $(63,3 \%)$. Sementara analisis regresi logistik menunjukkan hasil uji model keseluruhan terdapat pengaruh yang signifikan antara faktor-faktor dengan perilaku. Dan uji parsial menunjukkan bahwa hanya ada tiga faktor yang berkontribusi mempengaruhi perilaku menyimpang, ketiga faktor tersebut yaitu faktor pertemanan, faktor keluarga, dan faktor media massa.

Artikel yang ditulis oleh Ridwan M. Thaha dkk (2016), yang berjudul "Penyalahgunaan Obat Keras oleh Buruh Bangunan di Pergudangan Parangloe Indah Kota Makassar". yang dimuat dalam Jurnal MKMI, Vol. 12 No. 2, Tahun 2016, diakses pada 2 September 2019. Penelitian yang dilakukan bertujuan untuk mengetahui perilaku penyalahgunaan obat keras yang dilakukan oleh buuh bangunan di pergudangan Parangloe Kota Makassar. Pengumpulan data dalam penelitian ini dilakukan dengan wawancara mendalam kepada 11 informan dan observasi.

Dalam tulisan ridawan ia memaparkan bahwa, informan tidak mengetahui tentang dampak yang diakibatkan oleh obat keras. Obat keras mereka peroleh dari apotik langganannya. Kurangnya pengetahuan membuat mereka menyalahgunakan obat keras, karena mereka menganggap bahwa obat yang mereka gunakan merupakan suatu kebutuhan untuk bekerja sebagai buruh 
bangunan. Sehingga dalam penelitian ini dapat disimpulkan bahwa penyalahgunaan obat keras yang dilakukan oleh buruh di pergudangan parangloe dilakukan untuk kebutuhan bekerja dengan tujuan menghilangkan rasa lelah.

Artikel yang ditulis oleh Vive Vike Mantiri (2014), yang berjudul "Perilaku Menyimpang dikalangan Remaja di Kelurahan Pondang Kecamatan Amurang Timur Kabupaten Minahasa Selatan". Yang dimuat dalam Journal Volume III. No. 1. Pada tahun 2014. Diakses pada tanggal 2 September 2019. fokus penelitian Mantiri ditekankan pada bentukbentuk perilaku menyimpang dikalangan remaja di Kelurahan Pondang dan bagaimana peranan orang tua dalam penanggulangannya. Adapun cara untuk melakukan pengumpulan data dalam penelitian ini adalah kualitatif deskriptif yang dilakukan melalui cara observasi, wawancara dan dokumentasi. Teknik analisis dilakukan secara jalin menjalin berdasrkan pada proses pengamatan.

Dari hasil penelitian yang dilakukan menunjukkan bahwa kebanyakan remaja melakukan perilaku menyimpang disebabkan karena kurang perhatian dan kasih sayang dari orang tua mereka Sehingga peran orang tua sangat diperlukan. Remaja melakukan perilaku menyimpang seperti keluar rumah tanpa pamit, merokok, tindakan anti sosial, tindakan keriminal seperti mononton vidio porno, melakukan seks pranikah, narkoba. Faktor pergeseran budaya, perkembangan teknologi informaasi juga sangat berpengaruh karena merka mereka mentehui hal tersebut dari internet.

Berdasarkan beberapa penelitian di atas, telah menginspirasi penulis untuk meneliti yang sejenis dengan metode kualitatif. Adapun perbedaan penelitian sebelumnya dengan penelitian penulis lakukan yaitu; penelitian sebelumnya fokus untuk mengetahui motif pemabuk yang menggunakan Obat Batuk Komix, faktor apa saja yang mempengaruhi perilaku menyimpang seberapa besar pengaruh faktor tersebut menyebabkan perilaku menyimpang, tidak dibawa kesumber belajar. Dari penelitian sebelumnya penelitian ini memiliki perbedaan yakni membahas efek penyalahgunaan Obat Batuk Komix terhadap perilaku menyimpang dan membahas aspek-aspek yang bisa digunakan sebagai sumber belajar Sosiologi di Sekolah Menengah Atas (SMA).

\section{METODE}

Penelitian ini menggunakan jenis penelitian deskriptif kualitatif, yaitu penelitian yang bermaksud untuk mendeskripsikan masalah secara mendalam. Diantaranya yaitu untuk menjelaskan alasan remaja Desa Sapeken, Sapeken, Sumenep melakukan penyalahgunaan Obat Batuk Komix yang tidak sesuai dengan aturan penggunaan, Menganalisis upaya apa saja yang dilakukan oleh tokoh masyarakat, keluarga, komunitas dan pemerintah dalam menanggulangi penyalahgunaan Obat Batuk Komix yang terjadi di Desa Sapeken, Sapeken, Sumenep, Menjelaskan aspek-aspek yang terdapat dari Penyalahgunaan Obat Batuk Komix sebagai fenomena perilaku penyimpangan sosial di kalangan remaja Desa Sapeken, Sapeken, Sumenep yang bisa dimanfaatkan sebagai materi sumber belajar sosiologi di SMA.

Pendekaatan yang digunakan dalam peneitian ini adalah kualitatif deskriptif. Sugiyono (2015) menjelaskan, pada hakikatnya penelitian kualitatif adalah suatu metode dalam meneliti status sekelompok manusia, suatu objek dengan tujuan membuat gambaran atau lukisan secara sistematis, faktual dan akurat mengenai fakta-fakta atau fenomena yang diselidiki penelitian kualitatif menekankan pada peroses dibandingkan dengan hasil akhir. Jenis penelitian ini termasuk penelitian deskriptif. Penelitian deskriptif adalah penelitian yang tujuannya memberi gambaran atau uraian tentang fenomena ataupun gejala sosial yang diteliti dengan mendeskripsikan variabel mandiri, baik satu variabel ataupun lebih menurut indikator-indikator dari variabel yang diteliti tanpa menghubungkan atau membandingkan variabel yang diteliti 
untuk klasifikasi atau eksplorasi dengan mendeskripsikan sekelompok variabel yang berkaitan dengan variabel yang sedang diteliti. (Iskandar, 2008:61).

Secara spesifik penelitian ini berlokasi di Desa Sapeken, Sapeke, Sumenep Provinsi Jawa Timur. Pemilihan lokasi penelitian Dilakukan secara sengaja. Berdasarkan pertimbangan secara geografis Desa Sapeken, Sapeken, Sumenep. Alasan pemilihan lokasi ini karena banyak ditemui fenomena Penyalahgunaan Obat Batuk Komix yang dilakukan oleh remaja Desa Sapeken.

Sumber data dalam penelitian ini umumnya terbagi menjadi dua jenis yaitu; data primer dan data skunder. Kedua jenis data yang didapatkan diharapkan mampu membantu penulis dalam menjawab rumusan masalah yang sudah dipaparkan. Adapun sumber data dalam penelitian ini didapatkan dari data primer dan data skunder.

Teknik pengumpulan data yang digunakan dalam penelitian ini adalah sebagai berikut: Obeservasi, wawancara mendalam dan studi dokumen.

Teknik pengujian keabsahan data dalam penelitian ini menggunakan teknik trianggulasi dengan sumber, trianggulasi degan metode dan trianggulasi dengan teori. Dengan teknik analisis data yaitu: dengan cara mereduksi data, penyajian data, dan penarikan kesimpulan.

\section{HASIL DAN PEMBAHASAN}

4.2 Faktor Penyebab Remaja Desa Sapeken Melakukan Penyalahgunaan Obat Batuk Komix

Setelah melakukan Observasi, wawancara dan studi dokumen ditemukan beberapa informasi terkait faktor masalah penyalahgunaan Obat Batuk Komix yang dilakukan oleh remaja Desa Sapeken antara lain sebagai berikut:

4.2.1 Kelompok Bermain yang Kurang Baik (Pertemanan)

Persahabatan atau pertemanan merupakan perilaku kerja sama dan saling mendukung antara dua entitas yang merupakan sebuah kebajikan atau keutaman yang paling tak dapat dihindari oleh setiap individu, karena menghindari pertemanan adalah sebuah penyangkalan terhadap martabat manusia sebagai makhluk individual dan makhluk sosial. Karena itu, pertemanan adalah bahasa dan kegiatan manusia untuk memaknai hariannya. Atas tuntutan makhluk sosial ini, berlaku prinsip bahwa penghargaan tertinggi terhadap seorang sahabat tampak melalui apa yang dilakukan terhadapnya. Pada hakikatnya pertemanan memilki dua pengaruh. Pengaruh tersebut adalah pengaruh positif dan pengaruh negatif, bahkan yang terjadi pada remaja Desa Sapeken pertemanan merupakan salah satu hal yang sangat berpengaruh untuk terjerat pada perilaku menyimpang. Hubungan pertemanan dapat terjadi di tempat-tempat dimana kehidupan sosial berlangsung.

Hal tersebut sesuai dengan hasil observasi pada tanggal 23 Juli 2019, Seorang remaja yang yang berinisial DD (22 Tahun) datang dengaan sepeda motor sambil membelayer sepedaya yang segaja la pakaikan kenalpot Telo menyapa temannya yang berinisial IK (22 Tahun) yang sedang duduk di sebuah warung biasa tempat mereka nongkrong la mengatakan "Hei Cong Aikonyok barangte..?" yang artinya " hei kawan Gimana kabar barang kita" remaja yang berinisial IK pun menjawab dengan ekspresi senyum "Adoo Cong Misa Sen Cong, niaje itu sen lima'atus sabbu. Tapi Sekkat" yang artinya "Aduh gak ada uang kawan, Sebenarnya sih ada uang 500.000 tapi Sobek" temannya yang berinisial DD menjawab "aa coco iru paitunu beke aq makai melli e" yang artinya "emm cocok mana biar saya yang pakai untuk beli" temannya yang berinisial IK menjawab " oke". Teman teman yang ada disekitarnyapun tidak pernah mencagah hal tersebut tetapi mereka berkata lanjutkan saja tidak munkin ketahuan (mereka saling mendukung). Aktivitas pertemanan semacam ini merupakan salah satu contoh inteeraksi yang menimbulkan perilaku menyimpang. Dimana mereka saling mendukung satu sama lain untuk melakukan hal yang mereka tahu salah tetapi mereka lupakan 
karena mereka hanya mementingkan kebersaman mereka.

Dari hasil wawan cara juga memperjelas bahwa mereka melakukan penyalahgunaan Obat Batuk Komix karena ajakan kelompok bermaik (pertemanan) dimana remaja pelaku penyalahgunaan Obat Batuk Komix ini lebih memprioritaskan teman atau kelompok bermain mereka sehingga penyalahgunaan Obat batuk komix yang terjadi di Desa Sapeken semakin marak dilakukan oleh remaja Desa Sapeke.

4.2.2 Hubungan Keluarga yang Kurang Harmonis

Melemahnya hubungan keluarga secara sosiologis akan mempengaruhi perkembangan anak di dalam memahami nilai atau norma dalam suatu tatanan sosial. Seperti yang terjadi di Desa Sapeken sesuai dengan hasil observasi peneliti pada tanggal 26 Juli 2019, dimana salah satu keluarga pelaku yang kerap melakukan pertengakaran di depannya. Peristiwa tersebut membuat si pelaku tidak lagi merasa nyaman sehingga ia mencari hal tersebut di luar kediamannya hingga akhirnya ia benar-benar memutuskan untuk lebih sering bersosialisasi dengan lingkungan yang baru. Secara sosiologis peristiwa ini mengakibatkan sebuah keluarga mengalami disfungsi baik itu fungsi afektif (kasih sayang, perlindungan dan rasa aman) maupun fungsi ekonomi.

Berdasarkan pemaparan diatas hal ini sejalan dengan hasil wawancaraa bahwa Remaja Desa Sapeken melakukan penyalahgunaan Obat Batuk Komix karena mengalami tekanan dari keluarga mereka, merasa tidak diperhatikan. Sehingga mereka memilih untuk mencari perhatian diluar rumah dan mencari kelompok bermain baru dan mengikuti apa yang teman mereka lakukan dengan tujuan agar mereka dianggap ada dalam kelompoknya.

\subsubsection{Kurangnya Kontrol Sosial Dari Pemerintah Desa}

Pemerintah merupakan lembaga yang sangat membantu masyarakat dalam menyelesaikan suatu masalah sosial. Yang mana pemerintah memiliki tugas untuk menyelesaikan masalah sosial. Lemahnya kerjassama pemerintah akan mengakibatkan masalah yang berkepanjangan dalam hal ini penyalahgunaan Obat Batuk Komix yang terjadi di Desa sapeken. Tugas dari pemeintahan desa adalah mengayomi massyarakatnya, menyelesaikan masalah sosial yang terjadi di Desanya.

Berdasarkan hasil observasi diketahui bahwa penyalahgunaan Obat Batuk Komix oleh para pemuda dilakukan hampir setiap hari di waktu dan tempat yang sama terutama di tempat-tempat yang biasa menjadi tempat berkumpul (basecamp) para pecandu Obat Batuk Komix. Tempat berkumpul pelaku bukan menjadi rahasia umum lagi, pembuangan sampah kulit Obat Batu Komix tidak lagi dirahasiakan yang mana sepanjang jalan terutama pesisir ditemukan kulit Obat Batuk Komix yang berserakan. Fenomena ini terjadi berkelanjutan disebabkan kurang tanggapnya pemerintah Desa Sapeken.

Penyalaahgunaan Obat Baatuk Komix di Desa Sapeken secara terus menerus hal ini diakibatkan kerena kontrol sosial yang lemah. Berdaasakan temuan peneliti terkait faktor penyalahgunaan Obat Batuk Komix yang dilakukan oleh remaja Desa Sapeken karena kurangnya kerjasma masyarakat dengan pemerintah, pemerintah masih menganggap fenomena yang bersifat kasuistis. sehingga mereka leluasa untuk melakukan penyalahgunaan Obat Batuk Komix.

4.3 Upaya-upaya yang Dilakukan Dalam Menanggulangi Penyalahgunaan Obat Batuk Komix yang Terjadi di Desa Sapeken, Sapeken, Sumenep. penyalahgunaan Obat Batuk Komix yang dilakukan oleh Remajanya yang mengakibatkan perilaku menyimpang lainnya seperti yang telah dijelaskan di atas. Sehinggaa tokoh masyarakat, pemerintah, komunitas dan keluarga melakukan upaya-upaya dalam menanggulangi penyalahgunaan Obat Batuk Komix. Adapun upaya-upaya yang dilakukan oleh tokoh masyarakat, pemerintah, komunitas dan keluarga adalah sebagai berikut: 


\subsubsection{Upaya yang Dilakukan Oleh Tokoh Masyarakat \\ Tokoh masyarakat merupakan} orang yang sangat memiliki peran penting dalam suatu daerah untuk menyelesaikan suatu masalah, baik yang sifatnya besar maupun dalam sekala yang kecil. Adapun upaya-upaya yang dilakukan oleh tokoh masyarakat Desa Sapeken dalam menanggulangi penyalahgunaan Obat Batuk Komix yang membuat keresahan di tengah-tengah masyarakat desa sapeken, dalam hal ini yang dimaksudkan adalah tokoh agama.

1. Tokoh agama melakukan bimbingan kepada remaja pengguna maupun yang bukan pengguna.

2. Menyampaikan penyalhagunaan Obat Batuk Komix dalam ceramah.

3. Menciptakan suatu perkumpulan pemuda untuk melakukan Ronda malam.

1. Mengadakan pengajian dengan mengundang remaja pengguna maupun yang bukan.

2. Melakukan kerjasama dengan kelompok Pemuda persis

3. Melakukan kerjaasama dengan Kapolsek Desa Sapeken.

Berdasarkan temuan peneliti, serta hasil wawancara dengan kelompok yang melakukan penanggulangan diketahui untuk sementara upaya yang paling memberikan hasil yang baik diantanya juga yang termasuk adalah Upaya yang dilakukan oleh tokoh masyarakat baik kerjasama dengan komunitas dan kapolsek membuat penanggulangan penyalahgunaan Obat Batuk Komix menjadi lebih mudah dan memberikan efek yang positif untuk menanggulangi penyalah funaan Obat Batuk Komix yang marak tejadi di Desa Sapeken.

4.3.2 Upaya yang dilakukan Oleh Pemerintah

Pengendalian sosial atau kontrol sosial adalah proses yang digunakan oleh seseorang atau kelompok untuk mempengaruhi, mengajak, bahkan memaksa individu atau masyarakat agar berperilaku sesuai dengan norma dan nilai-nilai yang berlaku di masyarakat, sehingga tercipta ketertiban di dalam masyarakat.

Berdasarkan hasil waawancara, pemerintah Desa Sapeken melakukan rapat koordinasi di Balai Desa Sapeken yang berlangsung pada hari senin tanggal 29 februari 2016 pukul 09.00 WIB, dengan BPD, Forpimka, Tokoh masyarakat dan tokoh agama. Rapat tersebut membahas mengenai persoalan sosial budaya (Waria), Kesehatan Lingkungan (Kambing Yang berkeliaran) dan kenakalan remaja (Komix, Miras, Kebut-kebutan dan lainlain). Rapat berlangsung dihadiri oleh pemerintah Desa Sapeken, Ketua BPD Sapeken, Perwakilan Camat, Perwakilan Danramil, Perwakilan Kamladu, Perwakilan Kapolsek (Tidak Hadir) Tokoh Masyarakat dan Tokoh Agama, UPT Puskesmas Sapeken, UPT SMA.

Dari hasil rapat koordinasi yang dipimpin oleh Kepala Desa Sapeken dengan agenda rapat diantaranya yaitu: 1) Persoalan sosial budaya (Waria), 2) Kesehatan lingkungan ( kambing yang berkeliaran), 3) Kenakalan remaja (komix, miras, kebut-kebutan dan lain-lain). Menyimpulkan bahwa:

Kenakalan Remaja Persoalan penyalahgunaan Obat Batuk Komix sudah sangat membahyakan yang dilakukan oleh anak remaja dan pelajar SMA, SMP, bahkan anak SD. Karena itu perlu penanganan dari semua pihak baik Guru, Masyarakat, dan Orang tua, pemerintah Desa Sapeken akan membuat surat edaran kepada toko-toko agar tidak bebas menjual Obat Komix banyak kepada anakanak remaja/ pelajar. persoalan kendaraan (kebut-kebutan), berboncengan tiga oleh anak-dibawah umur, seeda motor yang menggunkan knalpot blong dilarang dan ditangkap oleh kepolisian. jam malam kendaraan motor (anak remaja) diabatasi sampai jam 23.00 WIB dan jika masih berkeliaran akan ditangkap oleh aparat.

Selain itu pemerintah Desa Sapeken juga melakukan upaya untuk lebih memperkecil angka penyalahgunaan Obat Batuk Komix yang sangat marak terjadi sampai tahun 2019. Adapun usaha usaha yang dilakukan pemerintah Desa 
Sapeken selain malakukan koordiansi, yaitu sebagai berikut:

1. Melakukan razia pada toko-toko.

2. Melakukan razia pada kos-kosan.

3. Melakukan pembinan kepada pelaku yang tertangkap.

4. Melakukan sosialisasi ke SMA dengan bekerja sama denagan UPT Puskesmas.

5. Melakukan penyuluhan kepada masyarakat.

6. Mengeluarkan surat persetujuan kepada pelaku yang tertangkap. yang berbunyi "saya siap untuk ditindak lanjuti ketika saya mengulanginya kembali".

4.3.3 Upaya yang Dilakukan Kapolsek Desa Sapeken

Sebagai salah satu lembaga yang berperan untuk mencegah sekalipun mengurus pelaku penyalahgunaan Obat Batuk Komix kapolsek sapeken telah melakukan berbagai cara untuk meminimalisir terjadinya penyalahgunaan Obat Batuk Komix maka kapolsek desa sapeken melakukan razia di kos-kosan, pelabuhan serta tempat tempat yang rawan terjadi penyalahgunaan Obat Batuk Komix melakukan.

1. Melakukan penggalangan kepada para pemuda untuk tidak mengkonsumsi Obat Batuk Komix secara berlebihan (menyalahgunakan Obat Batuk Komix).

2. Melakukan kontrol/patroli disetiap pelabuhan ketika ada kapal atau perahu yang memungkinkan membawa hal tersebut.

3. Melakukaan kontrol/patroli sekaligus menghimbau pemilik Toko agar tidak menjual Obat Baatuk Komix secara berlebihan.

4. Mellakukan pembinaan kepada para pemuda yang tertangkap menyalahgunakan Obat batuk Komix.

5. Melakukan tindakan Hukum/sidang dipiring kepada pengguna dan penjual Obat Batuk Komix berlebihan.

6. Melakukan patroli ketempat rawan terjadinya penyaalahgunaan Obat Batuk Komix.

4.3.4 Upaya yang Dilakukan Oleh
Kelompok masyarakat
Masalah sosial yang terjadi ditengah masyarakat Desa Sapeken telah berlarut-larut sehinga bebrapa kelompok masyarakat telah melakukan upaya untuk mencegah serta mendorong pelaku penyalahgunaan Obat Batuk Komix untuk berperilaku sesuai dengan kehendak kelompok atau masyarakat. Ada beberapa kelompok massyarakat yang berperan dalam penanggulangan penyalahgunaan Obat Batuk komix ini yaitu diantaranya kelompok Pemuda Persis dan kelompok kampung baru. Kelompok-kelompo masyarakat ini berperan dengan memiliki cara tersendiri. Adapun peran peran yang dilakukan adalah sebagai berikut;

4.3.4.1 Upaya Kelompok Pemuda Persis pemuda persis merupakan komunitas yang sangat memiliki peran penting dalam melakukan kontrol sosial terhadap masalah sosial yang kerep terjadi di Desa Sapeken. Salah satunya adalah penyalahgunaan Obat Batuk Komix yang dilakukan oleh remaja Desa sapeken. Sebagai salah satu kelompok yang berperan melakukan usaha dalam meminimalisir penyalahgunaan Obat Batuk Komix, komunitas pemuda persis melakukan kontrol sosial dengan cara melakukan kerjasama dengan aparat desa dan kapolsek Desa Sapeken tidak terlepas mereka juga mengandalkan pembimbing mereka yang merrupakan tokoh agama Desa Sapeken yaitu Ustat Haji Ad-dailami. Kerjasama yang dilakukan dengan aparat Desa dan kapolsek Desa Sapeken bertujuan untuk mempermudah peroses razia dan peroses hukum yang mana ketika ada pelaku yang tertangkap maka mereka malakukan kontak dengan kapolsek desa sapeken dan membawa ke kantor kapolsek desa sapeken. Setelah peroses yang dilakukan di kantor kapolsek Desa Sapeken seperti bimbingan tentang bahayan mengkonsumsi Obat Batuk Komix yang disampaikan kepada pelaku yang tertangkap yang dilakukan oleh kapolsek Desa Sapeken, maka pelaku akan menjalani peroses hukuman atau di bebaskan. Selain itu biasaya peroses ini juga tidak berhenti pada bimbingan yang dilakukan oleh aparat kapolsek Desa Sapeken tetapi juga bisa dikembalikan 
pada komunitas pemuda persis untuk melakukan bimbingan yang dilakukan oleh Ustat Haji Ad-daillami selama dua bulan peroses ini akan berlangsung setelah pelaku menandatangani surat persetujuan yang di saksikan oleh orang tua pelaku dan kepala desa sapeken.

Berdasarkan pemaparan di atas dapat kita ketahui bahwa pemuda persis memiliki peran penting dalam menanggulangi masalah sosial penyalahgunaan Obat Batuk Komix yang terus terjadi di Desa Sapeken. Komunitas pemuda persis juga telah melakukan kerjasama dengan aparat desa dan kapolsek desa sapeken untuk melakukan penanggunalangan masalah penyalahgunaan obat batuk komix yang telah berjalan sejak tahun 2016. Tetapi dalam melakukan penaggulangan tersebut pemuda persis juga memiliki kendalakendala dalam manjalani penyalahgunaan obat batuk komix yang terus dilakukan oleh para remaja Desa Sapeken.

Adapun kendala-kendala yang dihadapi yaitu kurangnya respon dari pemerintah Desa Sapeken, kurangnya kerjasama orang tuan pelaku dan kurangnya kerjasama masyarakat Desa Sapeken sehingga mengakibatkan masalah penyalahgunaan Obat Batuk Komix ini terus berkelanjutan.

4.3.4.2 Upaya Kelompok Kampung Baru Adapun upaya yang dilakukan oleh kelompok Kampung baru dalam memberikan kontriusi menanggulangi masalah sosial penyalahgunaan Obat Batuk Komik yang terjadi di Desa Sapeken yaitu diantaranya;

1. Melakukan ronda malam

2. Melakukan pembersihan semaksemak yang rawan dijadikan tempat Penyalahgunaan Obat Batuk Komix.

4.4 Aspek-aspek dari fenomena penyalahgunaan Obat Batuk Komix yang Bisa Dimanfaatkan Sebagai Sumber Belajar Sosiologi Untuk Sekolah Menengah Atas (SMA).

Berdasarkan hasil penelitian, ditemukan beberpa informasi terkait aspek-aspek dari masalah sosial penyalahgunaan Obat Batuk Komix yang bisa dijadikan sebagai sumber belajar sosiologi di Sekolah Menengah Atas (SMA), antaralain sebagai berikut:

a. Keterbatasn materi terkait penyalahgunaan maslah sosial penyalahgunaan Obat dalam buku teks yang digunakan oleh guru dalam memaparkan materi pelajaran sosiologi di Sekolah Menengah Atas (SMA), khususnya pada kelas XI yang berkaitan dengan materi pembelajaran Permasalahan sosial dalam masyarakat sesuai dengaan silabus mata pelajaran Sekolah Menengah Atas/Madrasah Aliah (SMA/MA), kurikulum 2013 (K-13) pada Kompetensi Dasar (KD) 3.2 dan Kompetensi Dasar (KD) 4.2. Meteri pembelajaran terkait dengan permasalahan sosial dalam masyarakat hanya menjelaskan permasalahan dalam masyarakat seperti kemiskinan, kriminalitas, kekerasam, kesenjangan sosial ekonomi, dan ketidak adilan. Tidak secara langsung membahas terkait fenomena masalah sosial penyalahgunaan Obat Batuk Komix yang terjadi di masyarakat.

b. Aspek-aspek dari fenomena penyalahgunaan Obat batuk Komix yang bisa dijadikan sebagai sumber belajar sosiologi untuk Sekolah Menengah Atas (SMA).

Berdasakan hasil analisis kurikulum dan silabus maslah sosial penyalahgunaan Obat batuk Komix ini bisa dimanfaatkan untuk sumber belajar Sekolah Menengah Atas (SMA) yaitu berkaitan dengan masalah sosial dalam masyarakat. Adapun potensi masalah sosial penyalahgunaan Obat Batuk Komix yang dilakukan oleh remaja Desa Sapeken yaitu sebagai berikut:

1. Faktor penyalahgunaan Obat Batuk Komix.

Penyalahgunaan Obat Batuk Komix yang dilakukan oleh remaja Desa Sapeken disebab oleh tiga faktor yaitu diantaranya kelompok bermain yang kurang baik, hubungan keluarga yang 
kurang harmonis, kurangnya koontrol sosial dari pemerintah Desa Sapeken.

a. Kelompok Bermain yang Kurang Baik (pertemanan)

b. Hubungan Keluarga yang Kurang Harmonis.

c. Kurangnya Kontrol Sosial dari Pemerintah.

2. Upaya Penanggulangan penyalahgunaan Obat Batuk Komix di Desa Sapeken.

Dalam melakukan penanggulangan masalah sosial tidak cukum jika hanya satu pihak yang melakukannya sehingga pada dasrnya semua pihak akan melakukan kerjasama untuk mencapai tuan yang sama. Dalam halnya permasalahan sosial penyalahgunaan Obat Batuk Komix yang dilakukan oleh remaja Desa Sapeken sehingga beberapa oknum atau kelompok melakukan upayanya, adapun kelompokkelompok yang melakukan tindakan penanggulangan masalah sosial penyalahgunaan Obat Batuk Komix ini antara lain:

a. Tokoh Masyarakan.

Adapun upaya yang dilakukan oleh tokoh masyarakat antaralai:

1. Melakukan kerjasama dengan pemerintah desa, aparat kepolisisan serta komunitas pemuda persis.

2. Melakukan bimbingan selama dua bulan kepada individu atau kelompok pengguna yang dititipkan oleh komunitas Pemuda Persis maupun kapolsek Desa Sapeken. Bimbingan ini dilakukan Setalah anak tersebut menandatangani surat persetujuan bahwa dia akan melaksanakan dan mengikuti bimbingan yang dilakukan oleh Tokoh agama Desa Sapeken yaitu Ustadz H. Ad-Dailami.

3. Menyampaikan bahaya penyalahgunaan Obat Batuk Komix melalui ceramahceramahnya.

4. Menghimbu kepada orang tua serta seluruh masyarakat untuk menjaga anak-anaknya lebih kondusif lagi.

b. Pemerintah Desa Saeken.

Adapun upaya yang dilakukan oleh pemerintah Desa Sapeken adalah sebagai berikut:

1. Melakukan razia pada toko-toko.

2. Melakukan razia pada kos-kosan.

3. Melakukan pembinan kepada pelaku yang tertangkap.

4. Melakukan sosialisasi ke SMA dengan bekerja sama denagan UPT Puskesmas.

5. Melakukan penyuluhan kepada masyarakat.

6. Mengeluarkan surat persetujuan kepada pelaku yang tertangkap. yang berbunyi "saya siap untuk ditindak lanjuti ketika saya mengulanginya kembali".

c. Kapolsek Desa Sapeken

Adapun upaya yang dilakukan oleh kapolsek Desa Sapeken antara lain sebagai berikut:

1. Melakukan penggalangan kepada para pemuda untuk tidak mengkonsumsi Obat Batuk Komix secara berlebihan.

2. Melakukan kontrol/patroli disetiap pelabuhan ketika ada kapal atau perahu yang memungkinkan membawa hal tersebut.

3. Melakukaan kontrol/patroli sekaligus menghimbau pemilik Toko agar tidak menjual Obat Baatuk Komix secara berlebihan.

4. Mellakukan pembinaan kepada para pemuda yang tertangkap menyalahgunakan Obat batuk Komix.

5. Melakukan tindakan Hukum/sidang dipiring kepada pengguna dan penjual Obat Batuk Komix berlebihan.

6. Melakukan patroli ketempat rawan terjadinya penyaalahgunaan Obaat Batuk Komix.

e. Upaya yang dilakukan oleh kelompok masyarakat. 
Upaya yang dilakukan kelompok Masyarakat Seperti yang dilakukan oleh Kelompok Pemuda Persis Dan Kelompok Pemuda Kampung Baru yaitu melakukan kontrol sosial dengan cara melakukan kerjasama dengan aparat desa dan kapolsek Desa Sapeken tidak terlepas mereka juga mengandalkan pembimbing mereka yang merrupakan tokoh agama Desa Sapeken yaitu Ustat Haji Ad-dailami. Selain melakukan kerja sama mereka juga melakukan kontrol sosial dengan cara melakukan ronda malam.

\section{SIMPULAN DAN SARAN Simpulan}

Berdasarkan hasil penelitian yang merujuk pada rumusan masalah serta hasil penelitian, dan pembahasan yang telah dipaparkan di atas, maka maka dapat disimpulkan sebagai berikut:

1. Penyalahgunaan Obat Batuk Komix dilakukan oleh remaja desa sapeken secara sengaja hal ini disebabkan oleh faktor pertemanan, keluarga dan kurangnya kerjasama pemerintah desa Sapeken, Diamana mereka mereka terpengaruh oleh teman, ingin dianggap ada dalam kelompoknya dan ingin dianggap lebih kuat, kurang harmonisnya keluaarga, kurangnya kerjasama

2. pemerintah desa untuk melakukan kontrol sosial.

3. Upaya-upaya dilakukan dalam menanggulangi penyalahgunaan Obat Batuk Komix ini yaitu melakukan kerjasama yang dilakukan oleh Tokoh masyarakat, pemerintah, kapolsek desa sapeken, komunitas. Hal ini dilakukan untuk mempermudah peroses penanggulangan seperti melakukan bimbingan, sosialisasi baik pada pelaku maupun yang bukan pelaku, dan yang paling utama adalah unntuk melakukan kontrol sosial di dalam masyarakat.

4. Aspek-aspek dari fenomena penyalahgunaan Obat Batuk Komix ini bisa digunakan sebagai sumber belajar sosiologi di Sekolah Menengah Atas (SMA), yang akan membantu antara lain sebagai berikut: Bisa membantu Guru dalam melengkapi keterbatasan materi terkait Penyalahgunaan Obat, yang bisa dijaadikan sebagai sumber belajar sosiologi untuk sekolah menengah Atas (SMA) yang berkaitan dengan Faktor penyebab penyalahgunaan Obat Batuk Komix dan Upaya-upaya yang dilakukan.

\section{Saran}

Berdasarkan rangkuman dan simpulan yang telah dipaparkan di atas, maka ada beberapa saran dari penulis skripsi ini. Adapun saran dalam skripsi ini dapat diuraikan sebagai berikut:

1. Desa wajib secara serius melakukan kontrol dan penindakan terhadap perilaku penyalahgunaan.

2. Masyarakat, terutama orang tua dan komunitas saling bersinergi di dalam upaya pemberantasan terhadap tindakan penyalahgunaan obat batuk komix.

3. Aparat penegakan hukum dalam hal ini polisi wajib secara serius dan intensif bekerjasama dengan masyarakat di dalam upaya pemberantasan terhadap tindakan penyalahgunaan obat batuk komix.

\section{DAFTAR PUSTAKA}

Anshari, M. 2009. Aplikasi Manajemen Pengelolaan Obat dan Makanan. Yogyakarta: Nuha Medi-ka.

Alodokter. 2018. "Komix". Tersedia pada https://www.alodokter.com/komix. (diakses tanggal 27, februari, 2019).

Harjatiningsih, D. P. (2015). "Analisis Faktor-faktor yang Mempengaruhi Prilaku Menyimpang pada Siswasiswi SMA Negeri 1 Parung". Jakarta: Universitas Islam Negeri Syarif Hidayatullah.

Iskandar. 2008. Metodologi Penelitian Pendidikan dan Sosial (Kuantitatif dan Kualitatif). Jakarta: GP Press. 
Refeiater, U. H. (2011). "Penyalahgunaan Narkoba". Jurnal Health \& Sport II, (hlm. 67-126).

Sugiyono. 2010 Metode Penelitian Pendidikan. Bandung: Alfabeta.

Silabus Mata Pelajaran Sekolah Menengah Atas/Madrasah Aliyah (SMA/MA). (2016). Jakarta: Kementrian Pendidikan dan Kebudayaan.

Ridwan, M, dkk.(2016). "Penyalahgunaan Obat Keras oleh Buruh Bangunan di Pergudangan Parangloe Indah Kota Makassar". Jurnal MKMI, Volume 21, Nomor 2 (hlm.118-126).

Mantiri, Vive, Vike. (2014). "Perilaku Menimpang di Kalangan Remaja di Kelurahan Pondang, Kecamatan Amurang Timur Kabupaten Minahasa Selatan". Journal Volume III. No. 1 (hlm. 1-13).

Maylinda, Y. W. (2016). Motif Pemabuk (Studi kasus Kebiasaan Mabuk Menggunakan Media Obat Batuk Komix pada Remaja di Kelurahan Purwanegara). Purwokerto: IAIN Purwokerto.

Moleong, Lexy J. 2014. Metode Peneltian Kualitatif. Edisi Revisi. Bandung: PT Remaja Rosdakarya. 